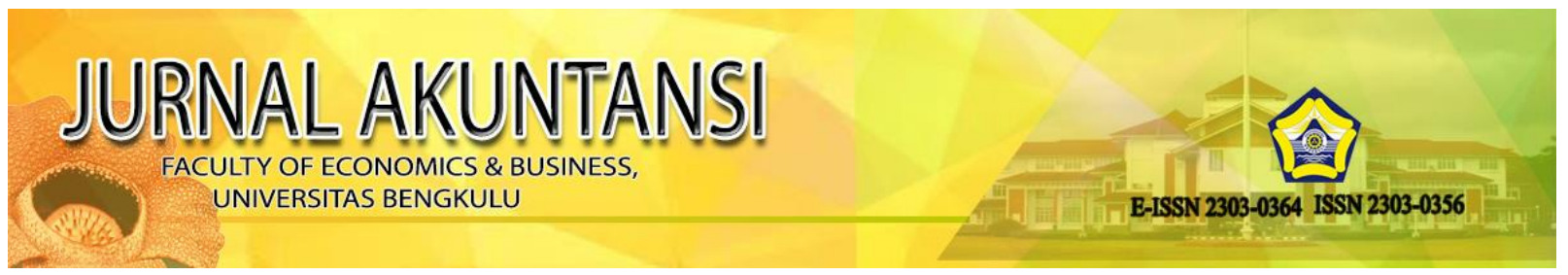

\title{
PENGARUH SOSIALISASI PERPAJAKAN, PEMAHAMAN, KEMUDAHAN DAN MANFAAT YANG DIRASAKAN WAJIB PAJAK UMKM TERHADAP KEPATUHAN MEMILIKI NPWP (Study Pada Wajib Pajak UMKM di Kota Bengkulu)
}

\section{THE INFLUENCES OF TAXATION SOCIALIZATION, UNDERSTANDING, EASINESS AND BENEFICIAL THAT WILL GIVE FOR MICRO SMALL MEDIUM BUSINESS ON OBEDIENCE POSSESS TAXPAYER NUMBER. (Study At Tax Payers In Bengkulu City)}

\author{
Dilla Kurniasi ${ }^{1}$ ), Halimatusyadiah, SE, M.Si., Ak, $\mathrm{CA}^{2}$ ) \\ Universitas Bengkulu, Jl. WR. Supratman,Kandang Limun, Muara Bangkahulu, Bengkulu \\ Dillakurniasi@gmail.com ${ }^{1}$ ), halimahtusyadiah@gmail.com ${ }^{2}$ )
}

\begin{abstract}
ABTRACT
The objective of this research is to prove the influence of the socialization of taxation, understanding of taxation, convenience of taxation and benefits that were felt by UMKM taxpayers against compliance to have NPWP. Data used in this research are primary data that were obtained from questionnaires that distributed to taxpayers. The number of questionnaires distributed were 155 questionnaires, but only 93 questionnaires that could be processed. Data were analyzed by multiple linear regression that using SPSS program. The result of this research showed that the socialization of taxation, understanding of taxation, convenience of taxation and benefits of taxation have positive influence and significant against taxpayers compliance to have NPWP. This research can contribute to KPP Pratama Bengkulu City to increase tax revenue target by collecting taxpayers to have a tax identification number (NPWP). The limitation of this research are on the number of questionnaires that distributed only in several sub-district in Bengkulu City. Therefore, further research is suggested to expand the research areas.
\end{abstract}

Key words: Socialization, Understanding, Taxation, Benefit, Compliance.

\begin{abstract}
ABSTRAK
Penelitian ini bertujuan untuk membuktikan pengaruh sosialisasi perpajakan, pemahaman perpajakan, kemudahan perpajakan, manfaat yang dirasakan terhadapkepatuhan memiliki NPWP dengan menggunakan theory of planned behavior. Data yang digunakan dalam penelitian ini adalah data primer yang diperoleh melalui penyebaran kuesioner pada Wajib Pajak UMKM di Kota Bengkulu. Jumlah kuesioner yang disebarkan adalah 155 kuesioner, tetapi hanya 93 kuesioner yang dapat diolah. Data dianalisis dengan menggunakan analisis regresi linear berganda dengan menggunakan program SPSS. Hasil penelitian menunjukkan bahwa sosialisasi perpajakan, pemahaman perpajakan, kemudahan perpajakan, manfaat yang dirasakan berpengaruh positif dan signifikan terhadapkepatuhan wajib pajak untuk memiliki NPWP. Penelitian ini dapat memberikan kontribusi bagi KPP Pratama Kota Bengkulu untuk meningkatkan target penerimaan pajak dengan cara menjaring wajib pajak untuk memiliki Nomor Pokok Wajib Pajak (NPWP). Adapun keterbatasan penelitian ini terdapat pada jumlah kuesioner yang hanya dibagikan di beberapa kecamatan di Kota Bengkulu. Oleh karena itu, penelitian selanjutnya disarankan untuk memperluas wilayah penelitian.
\end{abstract}

Kata Kunci: Sosialisasi, Pemahaman, Perpajakan, Manfaat, Kepatuhan. 


\section{PENDAHULUAN}

\section{LATAR BELAKANG}

Indonesia merupakan salah satu negara berkembang yang sedang melakukan pembangunan di segala bidang. Dalam melakukan pembangunan tersebut, pemerintah perlu memikirkan langkah agar dana pembangunan tidak bergantung pada pihak lainnya. Salah satunya adalah meningkatkan penerimaan negara sehingga dapat mengurangi ketergantungan terhadap pihak luar negeri dan Indonesia menjadi negara yang mandiri dalam pembangunannya. Sumber penerimaan tersebut dapat berasal dari penerimaan pajak negara maupun penerimaan bukan pajak. Masih rendahnya tingkat kepatuhan wajib pajak untuk memenuhi kewajiban perpajakannya. Provinsi Bengkulu merupakan salah satu provinsi yang sedang berkembang dalam bidang perdagangan, salah satunya pada sektor usaha mikro, kecil dan menegah terutama Kota Bengkulu. Realisasi penerimaan pajak Kota Bengkulu tidak seiring dengan pertumbuhan jumlah UMKM yang terus meningkat dari tahun ke tahun terutama di Kota Bengkulu. Hal ini dapat dilihat pada Tabel

\section{Tabel}

Perbandingan Jumlah UMKM di Kota Bengkulu dengan UMKM yang Terdaftar di KPP Pratama Kota Bengkulu

Sumber: KPP Kota Bengkulu dan Dinas UMKM Provinsi Bengkulu

\begin{tabular}{l|l|l|l}
\hline Tahun & $\begin{array}{l}\text { Jumlah UMKM } \\
\text { Kota Bengkulu }\end{array}$ & $\begin{array}{l}\text { UMKM } \\
\text { terdaftar di KKP } \\
\text { Kota Bengkulu }\end{array}$ & $\begin{array}{l}\text { Persentase } \\
(\%)\end{array}$ \\
\hline 2014 & 2078 & 906 & 43,5 \\
\hline 2015 & 3553 & 1194 & 33,6 \\
\hline 2016 & 3882 & 1024 & 26,37 \\
\hline
\end{tabular}

Dari Tabel tersebut menunjukkan bahwa dari tahun 2014 hingga tahun 2016 terjadi kenaikan jumlah UMKM yang cukup signifikan di Kota Bengkulu. Tetapi peningkatan jumlah UMKM terdaftar tersebut tidak sebanding dengan peningkatan jumlah UMKM yang ada di Kota Bengkulu. Hal tersebut terlihat dari jumlah UMKM yang mendaftarkan diri di KPP Pratama Kota Bengkulu pada tahun 2016 hanya mencapai 26,37 \% dari jumlah UMKM yang ada di Kota Bengkulu. Sedangkan sisanya sebesar 73,63 \% masih belum mendaftarkan usahanya dan belum memiliki NPWP. Hal tersebut menunjukkan bahwa di Kota Bengkulu terdapat permasalahan kepatuhan UMKM dalam memiliki NPWP.

Selain itu, rendahnya kepatuhan pemilik UMKM dalam melaksanakan kewajiban perpajakannya juga dapat terlihat dari rendahnya kontribusi pajak dari sektor UMKM terhadap penerimaan pajak Kota Bengkulu. Kontribusi penerimaan pajak dari sektor UMKM di Kota Bengkulu dapat dilihat pada Tabel

Tabel

Kontribusi Penerimaan Pajak dari Sektor UMKM Kota Bengkulu

\begin{tabular}{l|l|l|l}
\hline Tahun & $\begin{array}{l}\text { Penerimaan Pajak Kota } \\
\text { Bengkulu }\end{array}$ & $\begin{array}{l}\text { Penerimaan Pajak } \\
\text { dari Sektor UMKM } \\
\text { Kota Bengkulu }\end{array}$ & $\begin{array}{l}\text { Kontribusi } \\
(\%)\end{array}$ \\
\hline 2014 & Rp 614.141.762.979 & Rp 1.239.750.367 & $0,20 \%$ \\
\hline 2015 & Rp 789.497.996.883 & Rp 1.423.343.343 & $0,18 \%$ \\
\hline 2016 & Rp. 839.153.889.294 & Rp 550.363.155 & $0,06 \%$ \\
\hline
\end{tabular}

Sumber: KPP Pratama Kota Bengkulu, diolah (2017) 
Dari tabel tersebut menunjukkan bahwa kontribusi pajak dari sektor UMKM sangat rendah, yaitu tidak mencapai $1 \%$ dari jumlah penerimaan pajak di KPP Pratama Kota bengkulu. Jumlah penerimaan pajak tersebut tidak sebanding apabila dibandingkan dengan jumlah UMKM di Kota Bengkulu yang terus mengalami peningkatan. Hingga saat ini upaya untuk meningkatkan penerimaan perpajakan, terutama dari sektor UMKM terus dilakukan. Untuk memberikan dukungan bagi pengusaha yang berstatus Usaha Mikro Kecil dan Menengah (UMKM), pemerintah akan menaikan ambang batas atau treshold sebagai pengusaha kena pajak.

Sesuai dengan Peraturan Menteri Keuangan (PMK) Nomor : 197/PMK.03/2013 yang ditetapkan tanggal 20 Desember 2013 dan mulai berlaku efektif sejak 1 Januari 2014 bahwa batasan omset pengusaha kecil yang wajib dikukuhkan sebagai Pengusaha Kena Pajak atau PKP atau wajib menjadi Pajak Pertambahan Nilai yang berlaku senilai Rp4,8 miliar. Penentuan batasan PKP ini bertujuan agar pengusaha UMKM lebih mendapatkan keadilan dan kesenjangan yang tercipta bisa dikikis.

Untuk meningkatkan penerimaan pajak Direktorat Jendral Pajak melakukan upaya melalui penjaringan wajib pajak baru dimana wajib pajak nantinnya akan diberikan nomor pokok wajib pajak (NPWP). Dikarenakan masih rendahnya tingkat kepatuhan pemilik UMKM dalam memiliki NPWP maka penting untuk mengkaji mengenai faktor-faktor apa saja yang dapat mempengaruhi wajib pajak dalam memiliki NPWP.

\section{RUMUSAN MASALAH}

Rumusan masalah dari penelitian ini adalah Apakah sosialisasi perpajakan berpengaruh positif terhadap kepatuhan memiliki NPWP ?

1. Apakah pemahaman perpajakan berpengaruh positif terhadap kepatuhan memiliki NPWP ?

2. Apakah kemudahan perpajakan berpengaruh positif terhadap kepatuhan memiliki NPWP ?

3. Apakah manfaat yang dirasakan wajib pajak berpengaruh positif terhadap kepatuhan memiliki NPWP ?

\section{TUJUAN PENELITIAN}

Adapun tujuan dari penelitian ini adalah Untuk membuktikan sosialisasi perpajakan berpengaruh positif terhadap kepatuhan memiliki NPWP.

1. Untuk membuktikan pemahaman perpajakan berpengaruh positif terhadap kepatuhan memiliki NPWP.

2. Untuk membuktikan kemudahan perpajakan berpengaruh positif terhadap kepatuhan memiliki NPWP.

3. Untuk membuktikan pengaruh manfaat yang dirasakan terhadap kepatuhan memiliki NPWP.

\section{MANFAAT PENELITIAN}

Manfaat penelitian ini adalah:

1. Secara Teoritis

Hasil penelitian ini penelitian ini dapat menjadi pedoman, pembelajaran dan sumbangsih pemikiran mengenai pengembangan theory of planned behavior (TPB) yang dapat mempengaruhi kepatuhan wajib pajak UMKM dalam memiliki NPWP serta menambah bukti empiris mengenai pengaruh sosialisasi perpajakan, pemahaman perpajakan, kemudahan perpajakan dan manfaat yang dirasakan wajib pajak UMKM 
terhadap kepatuhan memiliki Nomor Pokok Wajib Pajak sehingga ilmu akuntansi perpajakan semakin berkembang dan dapat menjadi bahan referensi bagi penelitipeneliti selanjutnya

2. Secara Praktis

Bagi Direktorat Jendral Pajak khususnya KKP Kota Bengkulu diharapkan mampu memberikan masukan serta referensi dalam membuat kebijakan yang berhubungan untuk meningkatkan kepatuhan Usaha mikro, kecil dan menengah dalam memiliki NPWP melalui sosialisasi perpajakan, pemahaman perpajakan, kemudahan perpajakan dan manfaat yang dirasakan pemilik UMKM.

\section{KERANGKA TEORITIS DAN HIPOTESIS}

\section{SOSIALISASI PERPAJAKAN}

Sosialisasi pajak harus dilakukan secara teratur karena peraturan dan Sosialisasi perpajakan yang diadakan harus dapat menyampaikan semua informasi ke dalam wajib pajak. Sosialisasi pajak harus disampaikan dengan jelas agar wajib pajak dapat memahami informasi yang diberikan. Kejelasan dalam memberikan sosialisasi dapat dipengaruhi oleh cara atau media sosialisasi yang mungkin mudah untuk dimengerti oleh wajib pajak. Melalui sosialisasi pajak yang intensif dapat meningkatkan pengetahuan dan pemahaman calon wajib pajak mengenai semua hal yang berkaitan perpajakan. Tanpa adanya sosialisasi yang efektif kepada wajib pajak, khususnya pemilik UMKM maka para pelaku usaha akan mengalami kesulitan dalam memenuhi kewajiban perpajakannya.

Menurut Winerungan (2013) bahwa dengan kurang intesifnya sosialisasi yang diberikan akan berdampak pada rendahnya pengetahuan dan pemahaman wajib pajak sehingga berpengaruh pada kepatuhan pajaknya. Hal tersebut memberi informasi bahwa semakin baik memberi penyuluhan peraturan perpajakan yang berlaku akan meningkatkan kepatuhan UMKM untuk memiliki NPWP. Penelitian yang dilakukan oleh Putri (2013), menemukan bahwa sosialisasi pajak mempunyai pengaruh terhadap kepatuhan memiliki NPWP . Penelitian dari Meri,dkk (2015) menunjukan bahwa sosialisasi pajak berpengaruh signifikan terhadap Kepatuhan wajib pajak UMKM dalam memiliki NPWP dan juga penelitian Ummami (2015) menunjukan sosialisasi pajak dan penghasilan wajib pajak secara bersama-sama (simultan) berpengaruh terhadap kepemilikan NPWP pada pengusaha UMKM. Berdasarkan penjelasan tersebut, maka hipotesis yang kedua yaitu :

$\mathrm{H}_{1}$ : Sosialisasi perpajakan berpengaruh positif terhadap kepatuhan memiliki NPWP

\section{PEMAHAMAN PERPAJAKAN}

Sesuai dengan sistem perpajakan di Indonesia yang menggunakan self assesment system, dimana wajib pajak memiliki kesadaran dalam mendaftarkan diri untuk memiliki nomor pokok wajib pajak, kesadaran tersebut tidak dapat terjadi jika wajib pajak tidak memahami mengenai kewajibannya dalam urusan perpajakan. Pelaksanaan kewajiban perpajakan dapat terpenuhi dengan baik apabila wajib pajak memiliki pemahaman yang baik mengenai peraturan perpajakan yang berlaku. Hardiningsih (2011) mengatakan bahwa wajib pajak yang tidak memahami peraturan perpajakan secara jelas akan cenderung menjadi wajib pajak yang tidak patuh.

Hal ini yang menjadi dasar adanya dugaan bahwa pemahaman wajib pajak berpengaruh terhadap kepatuhan wajib pajak. Semakin tinggi tingkat pemahaman wajib pajak mengenai peraturan perpajakan maka kepatuhan wajib pajak dalam memiliki NPWP juga akan semakin meningkat. Tanpa pemahaman yang baik maka UMKM akan sulit dalam memenuhi kewajiban 
perpajakannya. Dari penelitian yang dilakukan oleh Masruroh (2013), Putri (2013), Wirapati dan Jati (2014), Meri (2015) menemukan bahwa variabel pemahaman Wajib Pajak berpengaruh positif terhadap tingkat kepatuhan UMKM dalam memiliki NPWP. Berdasarkan penjelasan tersebut, maka hipotesis yang pertama yaitu :

$\mathrm{H}_{2}$ : Pemahaman perpajakan berpengaruh positif terhadap kepatuhan memiliki NPWP

\section{Kemudahan Perpajakan dan Kepatuhan Memiliki NPWP}

Persepsi pengendalian perilaku pada theory of planned behavior merupakan persepsi seseorang tentang kemudahan atau kesulitan melakukan sesuatu. Saat ini, dalam memiliki NPWP wajib pajak diberikan kemudahan dalam urusan perpajakannya untuk pembuatan dan penghapusan NPWP itu sendiri. Selaras dengan kepentingan usaha wajib pajak maka, usaha untuk mempermudah wajib pajak dalam Memperoleh NPWP juga harus ditingkatkan. Terkait dengan kemudahan dan dalam rangka meraih kepercayaan masyarakat, Direktur Jenderal Pajak melakukan program modernisasi perpajakan secara komprehensif yang meliputi modernisasi Sistem Administrasi Perpajakan seperti, e-registration. Salah satu tujuan program modernisasi adalah mendapatkan tingkat kepatuhan perpajakan yang tinggi dan kepercayaan terhadap administrasi perpajakan (Prihantara dan Supriyadi: 2011).

Dari penjelasan di atas kepatuhan wajib pajak untuk memiliki NPWP secara positif berhubungan dengan faktor kemudahan. Penelitian Prihantara dan Supriyadi (2011) menemukan bahwa terdapat pengaruh positif dan signifikan pada faktor kemudahan terhadap kepemilikan NPWP. Semakin tinggi fakor kemudahan dalam urusan perpajakan maka semakin tinggi tingkat kepemilikan NPWP.

$\mathrm{H}_{3}$ : Kemudahan dalam urusan perpajak berpengaruh positif terhadap kepatuhan memiliki NPWP

\section{Manfaat yang Dirasakan dan Kepatuhan Memiliki NPWP}

Pada dasarnya, seseorang akan enggan untuk melakukan sesuatu yang tidak memberikan manfaat bagi dirinya. Theory of planned behavior menjelaskan bahwa ada keyakinan atau penilaian terhadap hasil dari suatu perilaku yang kemudian membentuk variabel sikap (attitude). Sikap mengacu pada sejauh mana seseorang mengevaluasi hal tersebut menguntungkan atau tidak menguntungkan dari perilaku yang akan dilakukan. Semakin banyak manfaat yang didapat oleh seseorang atas kepemilikan NPWP, maka tingkat kepatuhan untuk melaksanakan kewajibannya akan semakin tinggi (Maulana, 2013). Wajib Pajak akan mempunyai keinginan untuk memiliki NPWP apabila Wajib Pajak merasakan manfaat atas memiliki NPWP tersebut. Beberapa diantaranya adalah dengan memiliki NPWP maka pemilik UMKM akan mendapat kemudahan dalam pengurusan administrasi yang mensyaratkan NPWP, misalnya pengajuan kredit di bank, menjadi konsultan pajak maupun untuk mengikuti lelang pemerintah. Dalam penelitian yang dilakukan oleh Putri (2013), menemukan bahwa manfaat atas NPWP mempunyai pengaruh terhadap kepatuhan memiliki NPWP. Penelitian Putri (2013) sejalan dengan penelitian yang dilakukan oleh Priantara (2011) dan Prakoso (2011) dimana manfaat NPWP mempunyai hubungan positif serta berpengaruh signifikan terhadap kepatuhan wajib pajak. Maka hipotesis keempat yang diturunkan adalah sebagai berikut: $\mathrm{H}_{4}$ : Manfaat yang dirasakan berpengaruh positif terhadap kepatuhann memiliki NPWP. 


\section{METODE PENLITIAN}

\section{JENIS PENELITIAN \\ Jenis Penelitian yang digunakan dalam penelitian ini adalah penelitian kuantitatif. POPULASI DAN SAMPEL PENELITIAN}

Populasi dalam penelitian ini adalah Usaha Mikro Kecil dan Menengah (UMKM) yang memiliki NPWP sebanyak 1.024 ( KPP Pratama Kota Bengkulu). Teknik pengambilan sampel yang dipakai pada penelitian ini adalah non probability sampling. penelitian ini menggunakan rumus Slovin dengan tingkat kelonggaran 10\%, sehingga jumlah sampel yang didapat sejumlah 92 UMKM

\section{VARIABEL OPERASIONAL PENLITIAN}

\section{Variabel independen}

\section{Sosialisasi perpajakan (X1),}

Indikator variabel Sosialisasi perpajakandirujuk pada penelitian Wijayanto (2015), yaitu : Tatacara sosialisasi pajak, Frekuensi sosialisasi pajak, Kejelasan sosialisasi pajak yang diberikan Petugas pajak, Pengetahuan perpajakan

Pemahaman wajib pajak (X2) adalah semua hal tentang perpajakan yang dimengerti dengan baik dan benar oleh wajib pajak Indikator variabel pemahaman wajib pajak dirujuk pada penelitian Putri (2013), yaitu : Pemahaman terhadap fungsi pajak, Pemahaman terhadap kewajiban perpajakan, Sanksi yang diterima apabila tidak mendaftarkan usahanya sebagai wajib pajak, Fungsi NPWP, Mekanisme pendaftaran untuk mendapatkan NPWP.

\section{Kemudahan perpajakan (X3)}

Indikator variabel ini sesuai dengan Priantara dan Supriyadi(2011), yaitu: Kemudahan ketika membuat dan menghapus NPWP, Kemudahan menjalankan hak dan kewajiban perpajakan.

Manfaat yang dirasakan WP merupakan kegunaan yang dirasakan oleh WP jika memiliki NPWP. Manfaat yang dirasakan WP dalam memiliki tersebut diukur dengan indikator yang dirujuk dari penelitian Masruroh (2013) yaitu : Wajib pajak dapat melaporkan pajak dengan tertib, Wajib pajak akan memperoleh kemudahan pelayanan pajak, Wajib pajak akan mempermudah dalam pengajuan usaha, Wajib pajak akan memperoleh kemudahan pengajuan kredit bank.

\section{Kepatuhan UMKM dalam memiliki NPWP}

Indikator dari variabel merujuk pada penelitian Putri (2013) yaitu: Mendaftarkan diri untuk memiliki NPWP secara sukarela, Memiliki NPWP karena merupakan Wajib Pajak patuh.

\section{PENGUJIAN HIPOTESIS}

Nilai t digunakan untuk melihat pengaruh dari masing-masing variabel independen terhadap variabel dependen juga dilakukan dengan melihat nilai probabilitasnya (signifikansi), dimana apabila nilai signifikan $\mathrm{t}<0,1$, maka itu artinya variabel independen berpengaruh 
terhadap dependen, sebaliknya apabila nilai signifikan $t>0,1$ itu berarti variabel independen tidak berpengaruh terhadap variabel dependen (Ghozali, 2013).

\section{HASIL DAN PEMBAHASAN}

\section{UJI VALIDITAS}

Semua item intrumen kuisioner memiliki nilai signifikansi masing-masing variabel memenuhi nilai KMO MSA lebih besar dari 0,50 berarti bahwa alat ukur dalam penelitian ini adalah valid.

\section{UJI RELIABILITAS}

Semua variabel memiliki nilai koefisien Cronbach alpha lebih besar dari 0,6 sehingga dapat dikatakan instrumen pertanyaan yang digunakan dalam penelitian ini sudah reliabel.

\section{UJI ASUMSI KLASIK}

\section{Hasil Uji Asumsi Klasik}

\begin{tabular}{l|c|c|c}
\hline \multicolumn{1}{c|}{ Variabel } & Hasil & Persyaratan & Keterangan \\
\hline Normalitas & Sig $>0,05$ & Sig $>0,05$ & Distribusi Normal \\
\hline Multikolinearitas & Toleransi $>0,1$ dan VIF $<10$ & Toleransi $>0,1$ dan VIF & $\begin{array}{c}\text { Bebas } \\
\text { Multikolinearitas }\end{array}$ \\
\hline Heteroskedastisitas & Sig $>0,05$ & Sig $>0,05$ & $\begin{array}{c}\text { Bebas } \\
\text { Heteroskedastisitas }\end{array}$ \\
\hline
\end{tabular}

Sumber : Data primer diolah, 2017

\section{PEMBAHASAN}

\section{SOSIALISASI PERPAJAKAN TERHADAP KEPATUHAN MEMILIKI NPWP}

Sejalan dengan indikator-indikator yang digunakan dalam mengukur sosialisasi perpajakan membuktikan bahwa berpengaruh positif terhadap kepatuhan memiliki NPWP. Wajib pajak mendapatkan informasi tentang kemudahan mendaftarkan diri dengan e-NPWP, mendapatkan informasi tentang kasus-kasus perpajakan, aturan dan sanksi perpajakan dengan website pajak, koram, majalah serta dari penyuluhan-penyuluhan yang diberikan kantor pajak. TPB (theory of planned behavioral) menjelaskan perilaku Wajib Pajak dapat dilihat dari Sosialisasi perpajakan yang diberikan pemerintah yang akan membentuk norma subjektif (normatif beliefs) keyakinan individu terhadap harapan orang lain sebagai referensi sehingga mempengaruhi keputusan individu untuk memiliki NPWP. Hal ini dapat dilihat dari tabel data statistik, variabel sosialisasi perpajakan memiliki rata-rata nilai aktual lebih besar dari rata-rata teoritis. Hal tersebut dapat diartikan bahwa dengan pelayanan pajak, dimana dengan adanya pelayanan yang baik dari petugas pajak, sistem perpajakan yang efisien dan efektif, serta penyuluhan-penyuluhan pajak yang memberikan motivasi kepada wajib pajak agar taat pajak, dapat membantu mereka memilih perilaku taat pajak yaitu untuk memiliki NPWP.

\section{PEMAHAMAN PERPAJAKAN TERHADAP KEPATUHAN MEMILIKI NPWP}

Hipotesis kedua menyatakan bahwa pemahaman perpajakan berpengaruh positif terhadap kepatuhan memiliki NPWP secara statistik hipotesis ini diterima. Hal ini berarti semakin tinggi tingkat pemahaman perpajakan wajib pajak UMKM maka semakin meningkat 
kepatuhan UMKM dalam memiliki NPWP, sebaliknya semakin rendah pemahaman perpajakan wajib pajak UMKM maka akan semakin rendah tingkat kepatuhan UMKM dalam memiliki NPWP. Sejalan dengan indikator-indikator yang digunakan dalam mengukur pemahaman perpajakan membuktikan bahwa berpengaruh positif terhadap kepatuhan memiliki NPWP. wajib pajak memahami fungsi perpajakan sebagai sumber dana terbesar dari negara, memahami kewajiban perpajakan denagn mendaftarkan diri untuk memiliki NPWP, memahami sanksi yang diterima jika tidak memiliki NPWP, fungsi NPWP serta mekanisme pembuatan NPWP.

\section{KEMUDAHAN PERPAJAKAN TERHADAP KEPATUHAN MEMILIKI NPWP}

Hipotesis ketiga menyatakan bahwa kemudahan perpajakan berpengaruh positif terhadap kepatuhan memiliki NPWP secara statistik hipotesis ini diterima. Hal ini berarti semakin tinggi tingkat kemudahan perpajakan maka akan meningkatkan kepatuhan UMKM dalam memiliki NPWP, sebaliknya rendahanya kemudahan yang diberikan dalam hal perpajakan maka akan menurun tingkat kepatuhan pemilik UMKM dalam memiliki NPWP. Sejalan dengan indikator-indikator yang digunakan dalam mengukur kemudahan perpajakan membuktikan bahwa berpengaruh positif terhadap kepatuhan memiliki NPWP.

Menunjukan sebagian besar wajib pajak UMKM di Kota Bengkulu merasakan kemudahan dalam mendapatkan informasi mengenai pembuatan dan pengahpusan NPWP. Sehingga kualitas sistem pelayanan elektronik perpajakan merupakan salah satu cara Direktorat Jenderal Pajak (DJP) untuk membantu meringankan kewajiban perpajakan agar wajib pajak beranggapan bahwa untuk memiliki NPWP mudah dilakukan.

\section{MANFAAT YANG DIRASAKAN TERHADAP KEPATUHAN MEMILIKI NPWP}

Hipotesis keempat menyatakan bahwa manfaat yang dirasakan berpengaruh positif terhadap kepatuhan memiliki NPWP secara statistik hipotesis ini diterima Hal ini berarti semakin besar manfaat yang dirasakan wajib pajak maka semakin meningkat tingkat kepatuhan UMKM dalam memiliki NPWP, sebaliknya semakin kecil manfaat yang dirasakan maka akan semakin menurun tingkat kepatuhan pemilik UMKM dalam memiliki NPWP. Sejalan dengan indikator-indikator yang digunakan dalam mengukur kemudahan perpajakan membuktikan bahwa berpengaruh positif terhadap kepatuhan memiliki NPWP.

Dalam penelitian ini wajib pajak UMKM di Kota Bengkulu dapat mengajukan kredit di Bank dengan baik, melaporkan pajak dengan tertib dan memperoleh kemudahan pelayanan pajak. Dengan semakin banyaknya manfaat yang didapatkan wajib pajak UMKM dalam memiliki NPWP maka semakin meningkat tingkat kepatuhan wajib pajak UMKM dalam memiliki NPWP

\section{PENUTUP}

\section{KESIMPULAN}

1. Semakin intens dan efektif sosialisasi perpajakan yang diberikan seperti informasi untuk mendaftarkan diri dengan e-NPWP dengan pemberian informasi melalui penyuluhan langsung mau pun tidak langsung maka semakin besar kepatuhan UMKM dalam memiliki NPWP.

2. Semakin baik tingkat pemahaman wajib pajak UMKM terhadap perpajakan seperti pemahaman terhadap fungsi pajak, kewajiban perpajakan, sanksi yang di terima apabila tidak mendaftarkan usahanya sebagai wajib pajak, fungsi NPWP serta mekanisme pembuatan dan penghapusan NPWP maka semakin meningkat kepatuhan UMKM dalam memiliki NPWP 
3. Semakin banyak kemudahan yang di berikan dalam hal perpajakan yaitu pelayanan dari petugas pajak maka semakin meningkatkan kepatuhan UMKM dalam memiliki NPWP.

4. Semakin banyak manfaat yang dirasakan wajib pajak UMKM dalam memiliki NPWP seperti pengajukan kredit bank, pengajuan izin usaha, kemudahan mendapatkan pelayanan perpajakan maka akan semakin meningkat kepatuhan UMKM dalam memiliki NPWP.

\section{Saran}

Saran yang dapat diberikan untuk penelitian selanjutnya adalah:

1. Memperluas responden pada wajib pajak pemik UMKM yang tidak memiliki NPWP dan tidak hanya di Kota Bengkulu.

2. Menambahkan variabel independen lain selain dari sosialisasi perpajakan, pemahaman perpajakan, kemudahan perpajakan, serta manfaat yang dirasakan yang dapat mempengaruhi kepatuhan UMKM dalam memiliki NPWP seperti penghasilan wajib pajak.

\section{Keterbatasan Penelitian}

Adapun keterbatasan dari penelitian ini berupa:

1. Penelitian ini tidak apat di generalisasikan karena responden penelitian ini terbatas hanya menggunakan wajib pajak pemilik UMKM yang memiliki NPWP sehingga kurang mewakili keseluruhan wajib pajak yang ada di Kota Bengkulu

2. Dari hasil penelitian ada faktor lain yang dapat memberikan kontribusi yaitu penghasilan, dilihat dari tingkat omset yang dimiliki oleh UMKM Kota Bengkulu cendrung dibawah 300 juta sehingga membuat UMKM enggan mendaftarkan diri untuk memiliki NPWP

\section{DAFTAR PUSTAKA}

Ghozali, Imam. 2013. Aplikasi analisis Multivariate dengan program IBM SPSS 21 Edisi 7. Semarang: Badan Penerbitan Universitas Diponogoro.

Hardiningsih, Pancawati dan Nila Yulianawati. 2011. Faktor-Faktor Mempengaruhi Kemauan Membayar Pajak. Jurnal Dinamika keuangan dan Perbankan. Fakultas Ekonomi Universitas Stikubank, Semarang

Masruroh, siti. 2013. Pengaruh kemanfaatan NPWP, pemahaman wajib pajak, kualitas pelayanan, dan sanksi perpajakan terhadap kepatuhan wajib pajak (Studi empiris pada WP OP di Kabupaten Tegal). Journal of accounting. Fakultas Ekonomika dan Bisnis Universitas Diponegoro

Maulana, Irfan dan Fauziati, Popi dan Herawati.2013. Faktor-faktor yang mempengaruhi pengusaha kecil dan mikro mendaftar menjadi wajib pajak orang pribadi. Artikel ilmiah. Jurusan Akuntansi, Fakultas Ekonomi Universitas Bung Hatta

Meri, Betri, Sirajuddin dan Icha Fajriana. 2015. Faktor-faktor yang mempengaruhi kepatuhan pemilik usaha mikro, kecil, dan menengah (UMKM) dalam memiliki nomor pokok wajib pajak. (survey padawajib pajak pemilik umkm yang terdaftar di kpp pratama barat). Jurnal akuntansi. STIE MDP, Palembang

Peraturan Menteri Keuangan 197/PMK.03/2013 : perubahan atas peraturan nomor 68/pmk.03/2010 tentang batasan pengusaha kecil pajak pertambahan nilai 
Priantara, Diaz dan Bambang Supriyadi. 2011. Faktor-faktor yang Mempengaruhi Pengusaha Kecil dan Mikro Mendaftar Menjadi Wajib Pajak Orang Pribadi. Jurnal Akuntansi Dan Keuangan. Universitas Mercu Buana, Jakarta.

Putri, Wike Puspasari. 2013. Faktor-faktor yang mempengaruhi kepatuhan pemilik usaha mikro, kecil dan menengah (UMKM) dalam memiliki nomor pokok wajib pajak (NPWP) (survey pada wajib pajak pemilik UMKM yang terdaftar di KPP Pratama Batu). Jurnal Ilmiah Mahasiswa FEB Vol 1, No 2. Universitas Brawijaya.

Umammi, Khairah. 2015. Pengaruh manfaat yang dirasakan wajib pajak, kepercayaan terhadap aparat pajak, sosialisasi pajak, dan penghasilan wajib pajak terhadap kepemilikan nomor pokok wajib pajak (NPWP). Jurnal Jom FEKON Vol.2 No.2. Fakultas Ekonomi Universitas Riau, Pekanbaru, Indonesia

Winerungan, Oktaviane Lidya. 2013. Sosialiasai Perpajakan, Pelayanan Fiskus Dan Sanksi Perpajakan Terhadap Kepatuhan WPOP di KPP Manado dan KPP Bitung. Jurnal Emba Vol.1 No.3. Fakultas Ekonomi dan Bisnis, Jurusan Akuntansi Universitas Sam Ratulangi, Manado.

Wirapati, I Putu dan I ketut jati.2014. Faktor-faktor yang memengaruhi kepatuhan pengrajin dalam memiliki NPWP di Kabupaten Gianyar. Jurnal Akuntansi. Fakultas Ekonomi dan Bisnis Universitas Udayana, Bali 